\title{
Myth Thinking and the Mysterious China ${ }^{1}$
}

\author{
Yu Yurong ${ }^{2}$ \\ School of Literature and Communication, Central Minzu University of China, Beijing 100081, China
}

\begin{abstract}
Seeing from the other, China's image changes with process. Scholars understand China from the perspective of different myths with various conclusions and arguments, of which different ways of thinking resulted in mysterious China. From the subjectivity of it, the connotation of mysterious China needs the paraphrase and understanding from the local scholars' understanding of the myth.
\end{abstract}

Keywords: Myth, Mysterious Ways of Thinking, Mysterious China

Chinese library classification number: I276. 5 Literature No. A Article No. 1674-6627 (2013) 05-0098-04

\section{The Change of China's Image in the Eyes of the Other}

French sociologist Lévy-Bruhl (1857 1939), in his masterpiece Primitive Mentality, referred to people of color in Asia, Africa, Oceania and America as "primitive people” and "barbarians”, etc., whose national thinking was summarized as "intelligence of lower society". In Primitive Mentality, Bruhl used a large number of cases collected from "lower society" around the world to support a series of his concepts and arguments such as "collective representation", "law of mutual infiltration" and "original logic thinking”, among which China was mentioned most frequently. Although many of his ideas had great influence on the later studies on "primitive thinking", later researchers were more and more aware of the bias of "eurocentrism" and "racial inferiority”.

Lévy-Bruhl were influenced by the prevailing European view of China at the time. Since the end of the Middle Ages, China's image in the western perspective has changed several times: "in the process of getting rid of the medieval religious thoughts, some Confucian ideals were highly valued in Europe, Confucius was also known as the sage of Confucius in Europe, and Emperor Kangxi was recognized as the most ideal ruler. ...As trading and commerce developed in Europe, China's image has grown from bad to worse. From the end of the 18th century to the beginning of the 20th century, few European thinkers saw certain desirable traits in Chinese society and culture. "[1] [2]. The publication of Primitive Mentality came at a time when "few European thinkers had anything to recommend Chinese society and culture". This was the period when capitalism was increasingly consolidated in European countries, when the light of reason brought light to the darkness of religion in Europe, and when rapid progress was made in science. With a sense of rationality and scientific superiority, Lévy-Bruhl listed a large number of "superstitions" in ancient Chinese books and even in reality.

In the early 20th century, how do Lévy-Bruhl explain that the "land of superstition” was actually the "land

*This article was funded by the program of Shanghai Jiao Tong University titled "World-class Universities and First-class Subjects", and the program of Shanghai City titled "Shanghai Social Science Research and Innovation Base: Chinese Creation Myth Studies" (2017WSH002).

2 About the author: Yu Yurong (1980-), female, a native of Weihai City, Shandong Province, postdoctoral degree, School of literature and journalism, Minzu University of China, mainly engaged in the study of mythology and ancient Chinese literature. 
of reason" in the eyes of European thinkers during the Renaissance and the enlightenment? The glory of ancient Greek and Roman mythology were rediscovered during the Renaissance. Through the translation and introduction of missionaries, China, which was under the reign of emperor Qianlong and Emperor Jiaqing of the Qing dynasty, became a model of rational governance in the eyes of Voltaire, the leader of the enlightenment movement; Diderot, the central figure of the "encyclopedic school”, wrote two terms of "China" and "Chinese philosophy" in the encyclopedia. "He dabbled in the Chinese classics translated at that time, praised China as the most enlightened country, and praised Confucius doctrine that the country could be governed and ruled by reason and truth only". ${ }^{[2]}$ Kant, the last influential philosopher of the enlightenment, gave an in-depth explanation of reason, which greatly challenged the philosophy of religion. But Kant's view of China is a far different one from that of pre-enlightenment thinkers, pointing out that “we don't understand why Chinese scholars believe that eclipses occur because the dragon is devouring the sun or the moon, and they use drums to try to take the sun back from the dragon's mouth. This is probably a superstition from the period of ignorance. However, it has been maintained by the old-fashioned Chinese people, even though they have realized the ignorance.,[2] (67)

After Kant, two other famous German philosophers Hegel and Schelling also paid close attention to China. Hegel regarded China as an initial stage in the process of universal history, while Schelling emphasized the uniqueness of China beyond the process of universal history. Schelling's argument is more specific and pertinent than Hegel's, and his essay China-Philosophy of Myth expresses his view of China: “Among many mythological nations of the same age, the Chinese nation is one that has absolutely no myth. Its development seems to be completely divorced from the myth movement, and turned to a completely different side of human survival. For many countries and nations, the mythological process has played a powerful role, but China is a great and unique exception.” The key to understanding this passage is the concept of myth. Myth here refers to the "genealogy of myth", as scholars say: "people will argue that since ancient times, China has a large number of myths, immortal, myths of ghost, folklore and so on, how can it be a 'non-mythological nation'? But the key point is that Schelling's understanding of 'myth' specifically refers to a 'history of the birth of gods' or 'genealogy of gods', which is completely lacking in Chinese myths and legends." ${ }^{[3]}$. This paragraph can be understood in depth at different levels: China is not the "primary stage" of the universal historical process as Hegel understood it; China has always been a great and unique exception in the process of western society's development from low to high level. So what's unique? China is "a nation that has absolutely no myth", while "in many countries and nations, the mythological process exerts great power". Is China really a nation with no myth? The answer is negative. China is not lacking in myth, but in "the history of the birth of gods" or "the genealogy of gods". If we understand this classical discourse from these three levels, we can avoid such misunderstanding, or question such a "common sense”: western mythology has a relatively complete genealogy of mythology, so it is a nation with developed mythology; due to Chinese scattered myths and incomplete genealogy of myths, China is a nation without myths.

"Whether there is a genealogy of myth" is an important reason for the differences between Chinese and western cultures. However, does "being with genealogy of myth" indicate its myth developed, and "being without genealogy of myth" indicate its reason developed? This superficial derivation is where the "common sense" fallacy lies. However, the fact is that western culture with "genealogy of myth" completely separates mythical thinking from rational thinking, and finally tries to promote rational thinking and scientific thinking. "Myth" is eliminated completely in its thinking mode; However, Chinese culture, which "does not have the 
genealogy of myth", has never experienced the binary opposition between "myth” and "rationality", and has always been compatible with both.

\section{Mythical Thinking with Universal Explanatory Power}

Myth study is a kind of tradition in the west, and the angle of study varies from time to time. In the early stage of rationality, myths were expelled from the "Utopia" as absurd lies. After that, for a long time, myths were put on the opposite side of "rationality" and even regarded as absurd and empty words. In 1725, Vico explicitly put forward the concept of "mythology" in the New Science. Later, mythology, as an independent discipline, made great progress in the 19th century, and in the 20th century, both philosophers, thinkers, historians, ethnographers, psychologists and religious scientists all elaborated on mythology.

In the later works of Schelling, a mythological philosopher, mythological philosophy and apocalyptic philosophy account for a considerable proportion. German philosopher Ernst Cassirer saw this keenly: "a hundred years ago (the speech was delivered at Princeton University on January 18, 1945), Schelling gave his famous lectures on the philosophy of myth and the philosophy of revelation at the University of Berlin. It is the first time that myth has been recognized in the philosophical system and thus has been given citizenship in the realm of thought. Myths are treated as 'symbolic forms' such as language, art, religion and science, and are studied from a genetic perspective”. ${ }^{[4](201)}$

Inspired by Schelling's mythological philosophy, Cassirer reflected on the "scientific expansion" in the late 19th century and the early 20th century, and pointed out two fallacies in Lévy-Bruhl's Primitive Mentality: One is that human culture has long gone out of the age of myth, and this era will never return. Second, there is an unbridgeable gulf between our minds and those of primitive men. "In a sense," says Cassirer, "the 18th-century thinker saw in myth only a jumble of coarse superstitions-a hodgepodge of the most obscure, absurd, and fanciful ideas. The German romantic school, the antithesis of the French enlightenment philosophers, rejected and refuted this view. They see in the myth a completely different thing - a powerful and inescapable constructive force — that is the basis of human civilized life, poetry, art, religion, and history." "5] (191) After Schelling introduced mythological thinking into the realm of thinking, Cassirer further completed the subjects of "definition of category", "specific expression" and "description of various forms contained in mythological structure" in mythological thinking, which were of great significance. "The new research approach provides a new perspective and makes it possible to propose modern topics such as myth and social culture, myth structure and human thinking structure. The works of the French scholar Levi-Strauss represent a new development in this field. The ultimate purport of his three volumes of Mythology lies not in the study of mythology itself, but in the search for 'principles of thought formation that are universally valid for the psychology of all mankind”," [6] (93)

Compared with the concept of "myth", "mythical thinking” has more outrageous explanatory power and features of transition, integration and connection. Firstly, mythological thinking is in a transitional stage in the development of human thinking. After experiencing animal action thinking, human action thinking and representation thinking, human beings ushered in mythological thinking. Subsequently, mythological thinking was divided into artistic thinking and logical thinking, and logical thinking further developed into scientific thinking.

Secondly, the proportion of rationality and sensibility in mythological thinking is in a state of fusion. Myth thinking contains the dual crystallization of rationality and sensibility, which is different from the appearance 
thinking with "image" without "words" and the scientific thinking with "words" without "image". Thirdly, mythological thinking plays a penetrating role in human culture. Taking myth thinking as a clue, we can sort out the extending, following, transforming and differentiating of cultural "branches" of primitive religious ceremony, totem, myth, philosophy, language, literature, history, art and science, and finally regard culture as living.

On this basis, the question of "why has China's image changed several times in the vision of international sinology" can be well explained, that is, why is China "the country of reason" or "the country of superstition" in the eyes of foreigners? As we all know, one of the important characteristics of mythological thinking is its transitional nature: the combination of words and image, and the integration of rationality and sensibility, that is, the inalienable relationship between "reason" and "god". In China, the mythological thinking of "god" and "reason" is consistent ; The western culture has experienced the distinct separation of "god" and "reason", and "reason" has gradually gained the superior position.

In essence, the thinking of myth runs through Chinese culture, with both "god" and "reason". Therefore, when the west experienced theological darkness, the "rational" part of Chinese culture was highlighted in the eyes of the Other, and China was regarded as the "rational country"; When the west experienced the great development of rationality, scientific thinking became dominant, and the "god" in Chinese culture was prominent in the eyes of the Other, China was regarded as the "land of superstition".

\section{III. "Mysterious China” from the Perspective of Mythical Thinking}

Now let's go back to the example of China given by Lévy-Bruhl in Primitive Mentality: Gold and jade (and pearls) keep those who swallow them alive; In other words, these substances strengthen the souls or gods of those who swallow them. Like heaven, the souls belong to "Yang", so gold, jade and pearls can prevent the decaying of the dead and facilitate their reincarnation. ${ }^{[7](15)}$

In the Chinese, the association of image with existence becomes identical both materially and spiritually. In particular, a realistic portrait or sculpture is a living entity of alterego (another "I"), is the prototype of the soul house, not only so, it is the prototype itself... This vivid association is actually the basis of Chinese idol worship and spiritualism worship. ${ }^{[7](37)}$

Among the Chinese, the belief, the doctrine, and the axiom seem to have been firmly established that the ghosts of the dead maintain the closest contact with the living, almost to the same degree as they do with each other. There is, of course, a dividing line between the living and the dead, but it is so blurred that it is barely distinguishable. In any case, the interaction between the two worlds is very active. This association is both a source of happiness and a source of misfortune, so the ghost in fact dominates the fate of the living. In all Chinese literature from ancient to modern times, the coffin containing the corpse is called 'Shoucai' or 'bier (Lingjiu)'. ${ }^{\text {7] (297) }}$

These examples not only exist in China more than 100 years ago, but also exist in China today. For example, the influence of "gold" and "jade" on Chinese people has lasted for thousands of years. "The gold and jade predestined match" is the central clue of the Chinese classical novel A Dream of Red Mansions. The Beijing Olympic medal, called "gold inlaid with jade", is the latest display of the Chinese belief in jade in 2008. Influenced by the Christian culture, the west does not worship various statues and idols. But the Chinese worship of all kinds of "idols", such as the temple of Buddha shrine, "SongZi Guanyin”, "kitchen god” "god of door", etc., they believe in idol can bring peace auspicious. In the tomb-sweeping day every year, every family 
members offer incense to dead relatives. Burn "yuanbao" (shoe-shaped gold ingot) and "carriage" to the deceased relatives, and changed to "burn cheque book" and "car" this year, as they believe in the grave of dead loved ones can enjoy, and under the Jiuquan (nether world) bless them, the "ghost" for them is the source of "happiness" and "the root of evil".

Although the extreme of Lévy-Bruhl's Primitive Mentality is unobjective, in a sense, it can urge us to look at ourselves from the perspective of "the other": When western culture separated philosophy, literature, history and other disciplines and constantly refined them, myths were expelled from the "ideal country" and put into the opposite of rationality. However, Chinese disciplines were still inseparably fused together, which was the embodiment of the "integrity" of mythological thinking; When the western way of thinking developed into "logical thinking" and "artistic thinking", China developed various fields of culture in a comprehensive way of "mythological thinking”; The western developed logical thinking brought them the philosophy which is good at the metaphysical concept operation and the culture which takes the reason as the deep factor. Mythological thinking, on the other hand, is the "prototype code" for the conclusion of thousands of years of Chinese traditional culture. The reason why there is no much Chinese myths and the myths are scattered is precisely because they have deeply penetrated into ancient Chinese literature, philosophy and historical works. Therefore, China is not lack of myth, and can be called a real country of myth, Mr. Ye Shuxian described it as "China of myth", and believe that "the biggest feature of Chinese cultural tradition lies in its complete and diffuse mythological characteristics.” If we fail to recognize the fundamental influence of mythological thinking on Chinese culture, then no matter the study of Chinese philosophy, literature, aesthetics or history can truly trace its roots. Exploring the characteristics of Chinese traditional culture from the perspective of myth thinking is an effective way to decode. He therefore calls on the academic circle to change from the "Chinese myth" in the literary field to the "China of myth" in the overall cultural field. He also points out that "the concept of 'China of myth' will lead us back into the open history of Chinese culture by connecting literature, history, philosophy, history of thoughts, religion, psychology and other disciplines from an integrated vison” ${ }^{\text {[8] }}$.

We should also be clearly aware of its status that there is a blank field in mythology in Chinese academic history. Although mythology was introduced into China from Japan at the beginning of last century, it has been put under the name of folk literature for more than one hundred years and is only studied as one kind of literature. While the western world reexamines the root of myth from a comprehensive perspective, China still cleaves the original family of "literature, history and philosophy" in Chinese culture with rigid science and increasingly detailed discipline system, which is worthy of deep reflection by scholars.

\section{References}

[1] [Germany] Xie Ruichun, German thinker on China [M]. Nanjing: Jiangsu people’s publishing house, 1995.

[2] Liang Zhenhui. The influence of the translation and introduction to Chinese Confucianism on the European enlightenment -- A case study of French enlightenment thoughts [J]. Journal of Changji university, 2010(3)

[3] Xian Gang, Hegel and Schelling on the status of China in the "universal history” [J]. Journal of Yunnan university, 2010(4).

[4] [France] Brisson. Plato’s view of myth [A]. Plato, mythological poet [C]. Beijing: Huaxia publishing house, 2010.

[5] [Germany] Ernst Cassirer. Symbol, myth and culture [M]. Translated by Li Xiaobing, Beijing: Oriental press, 1988.

[6] Ye Shuxian, An Exploration of the irrational world [M]. Chengdu: Sichuan people’s publishing house, 1988.

[7] [France] Levi - Bruhl. Primitive Mentality [M]. Translated by Ding you,. Beijing: Commercial Press, 1985.

[8] Ye Shuxian, History of Chinese myth -from "Chinese myths” to "China of myth" [ J ] Journal of Baise University, 2009(1)

[Responsible Editor Yang Deliang] Date received: July 14, 2013 